\title{
EFFECT OF LONG TERM EXPLOATATION ON STRUCTURE AND PROPERTIES OF X20CrMoV11-1 STEEL
}

\author{
Ladislav KANDER, Petr ČížEK, Šárka STEJSKALOVÁ \\ MATERIAL AND METALLURGICAL RESEARCH Ltd., Ostrava, Czech Republic, EU, \\ ladislav.kander@mmvyzkum.cz
}

https://doi.org/10.37904/metal.2019.845

\begin{abstract}
This paper deals with effect of long-term exploitation on structure and mechanical and fracture properties of X20CrMoV11-1 grade steel. Mechanical properties were evaluated both using standard test specimens and small punch test (SPT). Obtained results were compared with received state conditions. Creep properties, crack growth rate as well as fracture toughness tests were carried out too.
\end{abstract}

Keywords: Mechanical properties, X20CrMoV11-1 steel, fracture behavior, crack growth rate, creep properties

\section{INTRODUCTION}

X20CrMoV11-1 steel grade belongs to the martensitic 9-12\% Cr steels that are used for the hottest parts in steam boilers, which are main steam and hot reheat lines, outlet headers, and superheaters. This steel represents optimal combination of material properties. Steel represents the optimum combination of material properties defined by the maximum steam and temperature pressure at which highly stressed pressurized components can be designed with wall thicknesses that allow fast temperature changes during boiler start-up and load changes. The introduction of martensitic $12 \% \mathrm{CrMoV}$ steels for thick-section boiler components enabled the construction of the first flexible supercritical power plants in the 1980s. The introduction of the creep strength-enhanced $9 \%$ Cr martensitic steels P91 and P92 in the 1990s and 2000s was the basis for the development of ultra-supercritical power plants with $600{ }^{\circ} \mathrm{C}$ live steam temperature, which is current state today [1].

The first installation of steam pipes made form steel X20CrMoV11-1 has now been in operation for more than $300,000 \mathrm{~h}$ at $535^{\circ} \mathrm{C}$, and a number of supercritical plants have passed $150,000-200,000 \mathrm{~h}$ of operation at 540$560{ }^{\circ} \mathrm{C}$. Reviews of damage experience with the X20 steel have shown an exceptionally low occurrence of Type IV cracking for this steel, with many plants showing total absence of type IV cracking [2,3,4]. A number of reasons can be given for this behaviour: The quality of pipe hanger systems has been improved compared to the older power stations with pipe systems made of low-alloyed steel, and more attention has been paid to the design of the pipe system to reduce system stresses. This has contributed to the suppression of type IV cracks. Also, the fact that stronger steel can be less sensitive to type IV cracking is of significance here [5]. The very low defect rate of welds means that the overall service performance of the X20CrMoV11-1 steel in steam pipes must be characterized as excellent. There have, however, been a few parent material problems with the steel caused by incorrect production and heat treatments leading to low creep strength material in some components, in particular, steam pipe bends [6].

\section{EXPERIMENTAL MATERIAL}

X20CrMoV11-1 steam pipeline operated at temperature of $535^{\circ} \mathrm{C}$ and pressure of $13.5 \mathrm{MPa}$ for 135000 hours has been used for investigation. The comprehensive analysis including assessment of mechanical properties, yield strength at elevated temperatures, fracture properties and fracture toughness, crack growth rate, microstructure and creep properties was done. Assessment using small punch test method was used too. 
Chemical composition of the steel under investigation is given in the Table 1.

Table 1 Chemical composition of analysed X20CrMoV11-1 steel

\begin{tabular}{|c|c|c|c|c|c|c|c|c|c|c|c|}
\hline & $\mathbf{C}$ & $\mathbf{M n}$ & $\mathbf{S i}$ & $\mathbf{P}$ & $\mathbf{S}$ & $\mathbf{C r}$ & $\mathbf{V}$ & $\mathbf{M o}$ & $\mathbf{N i}$ & $\mathbf{C u}$ & $\mathbf{A l}$ \\
\hline Steam pipeline & 0.20 & 0.47 & 0.18 & 0.012 & 0.002 & 10.56 & 0.25 & 0.88 & 0.69 & 0.15 & 0.007 \\
\hline $\begin{array}{c}\text { X20CrMoV11-1 (EN } \\
\text { 10216-2) }\end{array}$ & 0.17 & max. & 0.15 & max. & max. & 10.0 & 0.25 & 0.8 & 0.3 & max. & max. \\
\hline
\end{tabular}

\section{RESULTS}

The steel X20CrMoV11-1 is designed for operation at temperature of $540-560^{\circ} \mathrm{C}$, so steel under investigation was operated at the low bottom of designed temperatures. In order to assess degradation of material properties due to operation, actual material properties after 135000 operating hours were compared to the state as received given by inspection certificate TÜV. Actual mechanical properties and mechanical properties in state as received are given in Table 2. The standardized values according to EN 10216-2 for the steel on the matter were added, too.

Table 2 Mechanical properties of analysed X20CrMoV11-1 steel pipe

\begin{tabular}{|c|c|c|c|c|}
\hline Steam pipeline & $\mathbf{R}_{\mathrm{p} 0.2}[\mathrm{MPa}]$ & $R_{m}[\mathrm{MPa}]$ & $\mathrm{A}[\%]$ & $\mathrm{Z}[\%]$ \\
\hline Outer surface & 547 & 754 & 20.3 & 51.2 \\
\hline Inner surface & 544 & 750 & 19.8 & 51.0 \\
\hline $\begin{array}{c}\text { Inspection certificate TÜV } \\
(18.3 .1998)\end{array}$ & 573 & 767 & 19.0 & - \\
\hline $\begin{array}{l}\text { X20CrMoV11-1 } \\
\text { (EN 10216-2) }\end{array}$ & $\min .450$ & $630-830$ & - & - \\
\hline
\end{tabular}

In comparison of mechanical properties of exposed pipe and pipe in as received state is evident that long-term operation of pipe has caused a moderate decrease of both yield strength and tensile strength. At same time obtained values of tensile strength are in a good agreement with measured hardness values. The average value of analyzed pipe is $257 \mathrm{HV}$ [7].

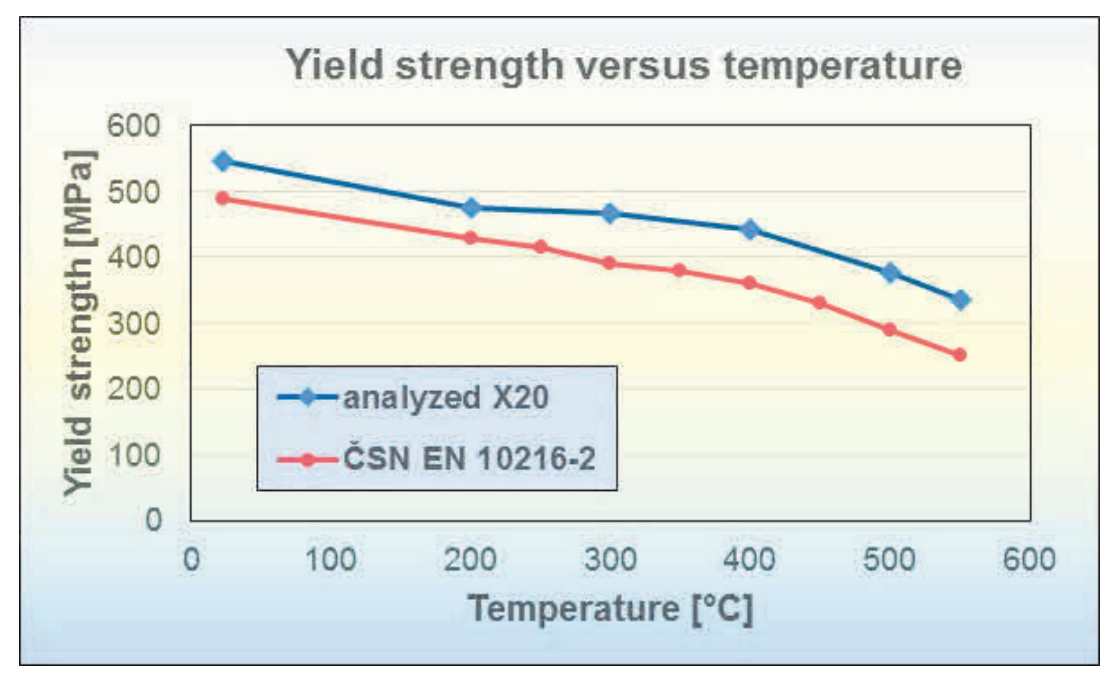

Figure 1 Yield strength versus temperature 
The analysis of mechanical properties was added by assessment of yield strength at elevated temperature that shows very good results. After 135000 operating hours yield strength of analyzed pipe lies above standard values in the whole temperature interval (from $200^{\circ} \mathrm{C}$ to $550{ }^{\circ} \mathrm{C}$ ) [7] (see Figure 1).

Also, microstructure analysis of exposed pipe did not show any degradation of material. The microstructure consists of tempered martensite with randomly dispersed small and isolated islands of $\delta$-ferrite, but without any signs of creep damage (coarse carbide particles, cavities, etc.). Example of microstructure of the exposed pipe is given in Figure 2.
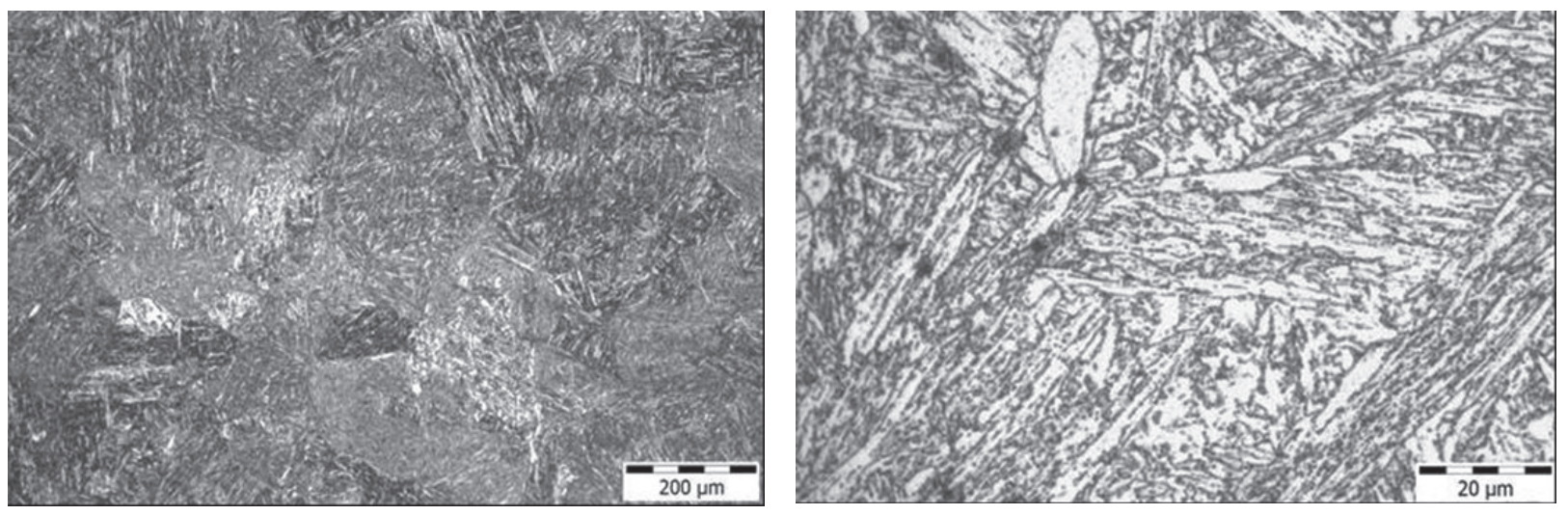

Figure 2 Microstructure of analyzed pipe

Nevertheless, the greatest change was seen in the assessment of fracture behaviour. Impact energy determined by impact test reached the value of just $35 \mathrm{~J}$ compared to the value of $106 \mathrm{~J}$ declared by Inspection certificate TÜV in state as received. Drop of Charpy V-notch energy shows that long term operation of analysed steel at the temperature of $535{ }^{\circ} \mathrm{C}$ has degraded mainly plasticity and toughness. This fact is confirmed by the low level of upper shelf of curve impact energy versus temperature (see Figure 3 ). The transition temperature (DBTT) at which the percentage of shear fracture on the fracture surface of Charpy $V$ standard specimen equals 50 was determined at $30^{\circ} \mathrm{C}$.

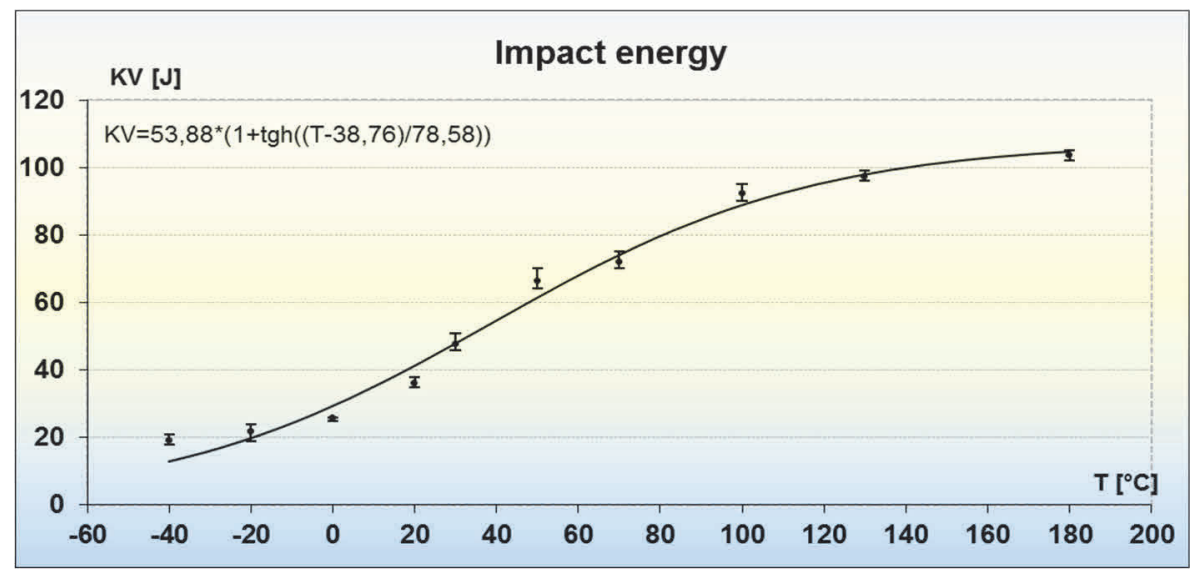

Figure 3 Impact energy versus temperature

In addition to the fracture behaviour of steel was assessed using the small punch test method. SPT method just confirmed the degradation of fracture behaviour of exposed pipe. The curve of SPT fracture energy is flat and the fracture energy at all measured temperatures is very low (see Figure 4). The transition temperature TSP obtained by small punch testing is often correlated with the DBTT obtained by Charpy using the following equation: 
$\mathrm{T}_{\mathrm{SP}}=\alpha^{*} \mathrm{DBTT}$ Charpy

between DBTT and the corresponding SP transition temperature $\mathrm{TSP}_{\mathrm{SP}}$, measured in a series of SP tests typically ranging from $-196{ }^{\circ} \mathrm{C}$ to $25^{\circ} \mathrm{C}$. The SP specimen orientation is such that the normal to the punch disk plane is parallel to Charpy specimen crack propagation direction. TSP is determined as the temperature where $E_{S P}$ has its mean value of the highest and the lowest values in the transition region, by intersecting the smooth curve fitted from the energy versus temperature data [8]. The Tsp was assessed at $141 \mathrm{~K}$.

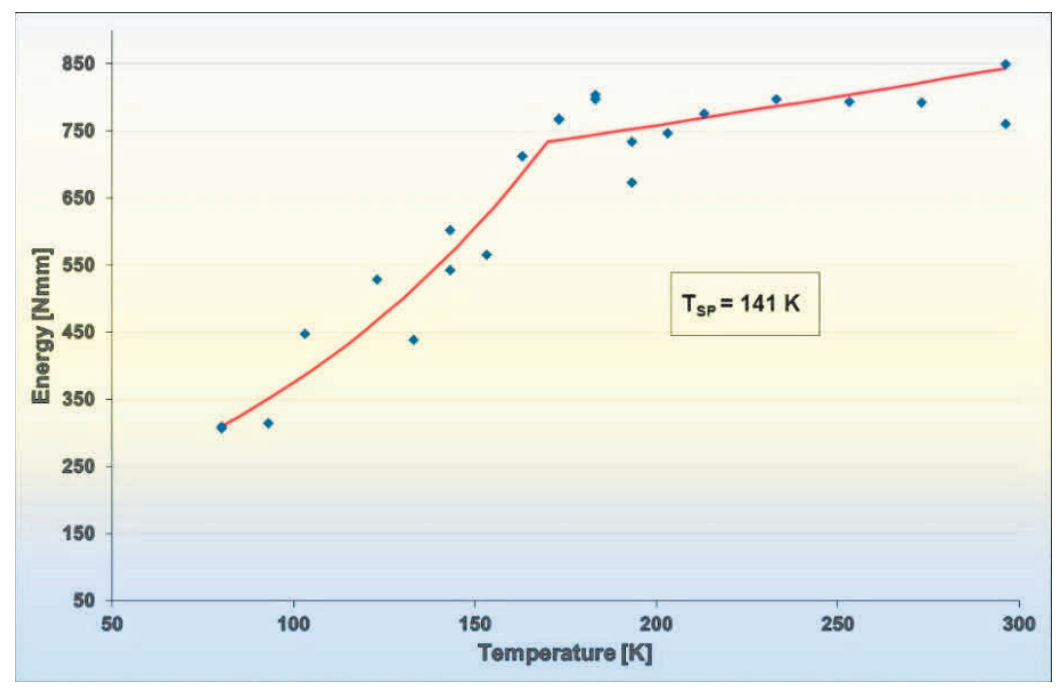

Figure 4 Temperature dependence of SPT fracture energy

The correlation factor $\alpha$ of analysed steel was determined at 0.46 , while the correlation factor was found to be from 0.41 to 0.43 for typical steels most often used in power industry [8]. It is evident that the correlation factor of long-term operated steel is situated outside of this interval. To confirm this fact, Tsp was evaluated once more according to standard procedure EN 15627 [8]. This method assessed TSP using the normalized SP energy (see Figure 5). According to this method was Tsp determined at $140 \mathrm{~K}$. So, this value is in very good accordance with evaluation shown in Figure 4.

All the facts mentioned above show that the higher value of correlation factor $(\alpha=0.46)$ indicates degradation of fracture behaviour due to long term exposure in creep conditions.

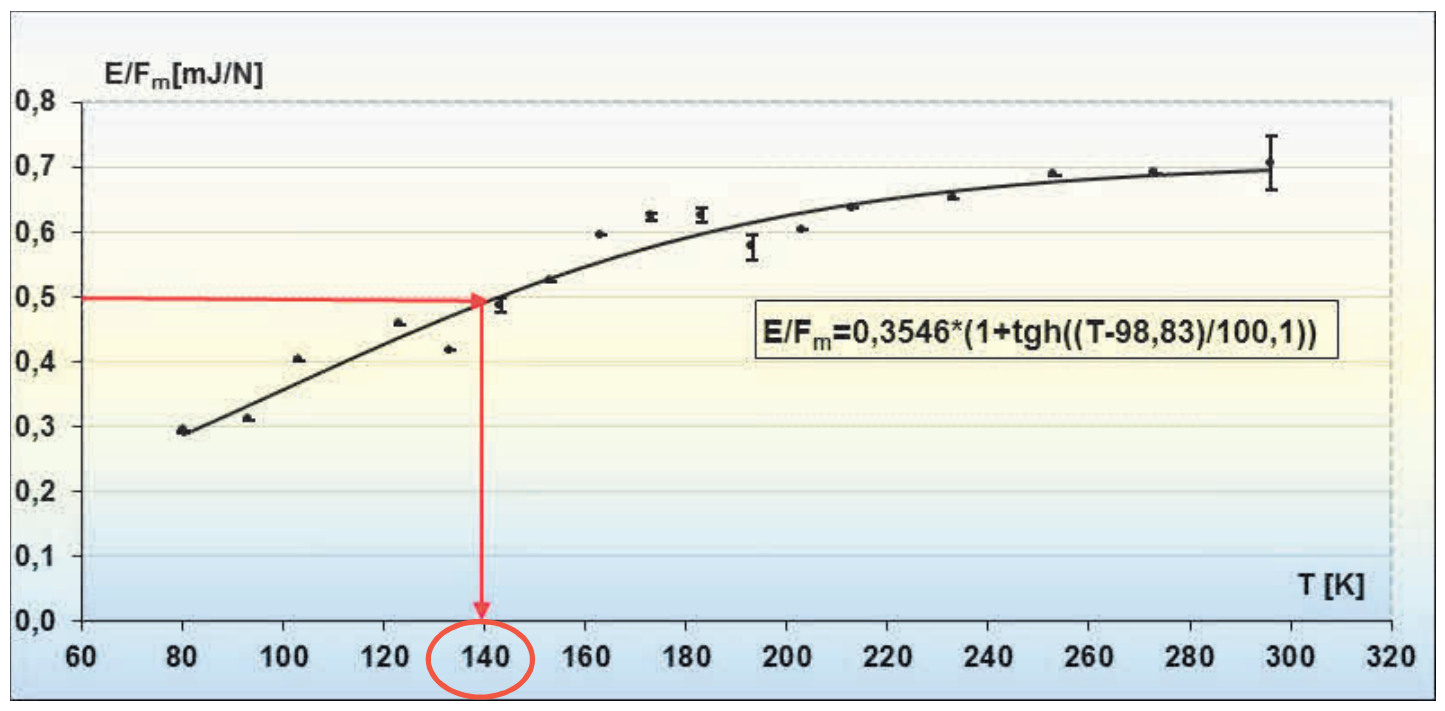

Figure 5 Determination of $T_{\mathrm{SP}}$ using the normalised energy 
Figure 6 shows fatigue crack growth curve of X20 steel focused on Paris law region and reference ASME curve for same asymmetry $(R=0.1)$ [9]. It can be clearly seen that fatigue crack growth rate is accelerated due the long term service. Actual crack growth rate behaviour is on acceptable limit. Such result corresponds well with previous facts indicated from impact test and SPT.

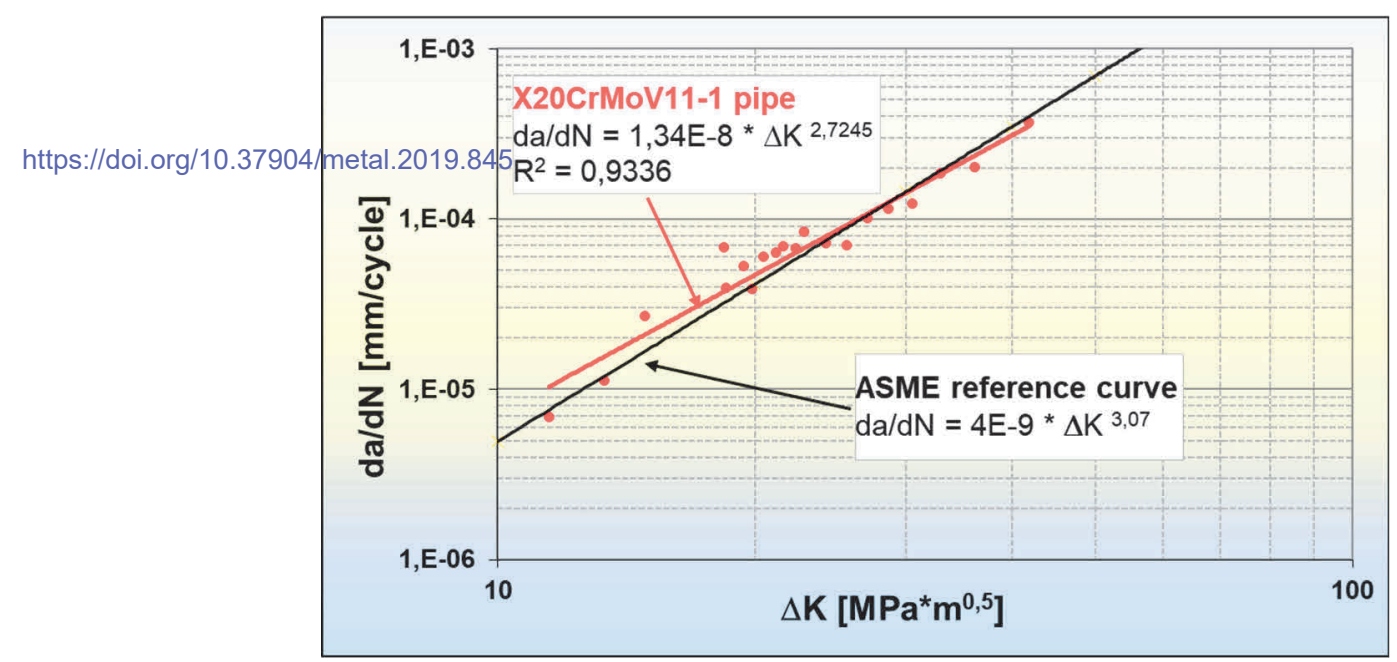

Figure 6 Comparison of the fatigue crack growth rate of X20CrMoV11-1 with ASME reference curve

\section{DISCUSSION}

Though the steel was operated very close to the lower limit of designed temperature and the applied stress was also too low to cause strong degradation of microstructure and/or material properties by creep, there were observed signs of partial consumption of lifetime. The mechanical properties changed a little bit and no cavitation damage was observed, but the greatest change was evaluated in fracture properties. Impact energy at room temperature dropped by nearly $65 \%$, which is evident sign of material degradation, and it is wellknown damage parameter in boiler drums [10]. However, the higher DBTT is not critical damage factor, value of FATT $\left(+30^{\circ} \mathrm{C}\right)$ does not seem to be critical because of the high service temperature. The calculated SPT FATT correlation factor $\alpha=0.46$ (Equation 1 ) is higher than the common range observed in most power plant steels [8]. This change is undoubtably caused due to effect of long-term exploitation. Similar effect can be seen in the Figure 6 fatigue crack growth rate is accelerated and shifted to the ASME limit due to exploitation.

Nevertheless, thanks to the not very demanding operating parameters, the analysed X20CrMoV11-1 pipe can be exploited further in service without danger of premature failure with respect to the findings presented in this paper regarding fracture properties at room temperature.

\section{CONCLUSION}

In terms of presented experimental work the long term exposed X20CrMoV11-1 was analysed. The comprehensive assessment included the analysis of mechanical properties, microstructure examination, evaluation of fracture behaviour and crack growth rate. Significant changes have been observed in fracture and crack growth rate properties. Both of them showed drop due to long term exploitation in creep conditions. Further work focused on evaluation of fracture toughness and actual creep properties is continuing within the frame of project. 


\section{ACKNOWLEDGEMENTS}

This paper was created in the frame of the Project No TK01020160 "Complex procedures of material engineering to ensure the safe operation of innovated blocks of fossil power plants" financed by Technology Agency of the Czech Republic.

\section{REFERENCES}

[1] HALD, J. High-alloyed martensitic steel grades for boilers in ultra-supercritical power plants. Woodhead Publishing Series in Energy: Number 104. Edited by Augusto Di Gianfrancesco, 2017, pp. 77-97.

[2] STORESUND, J., BORGGREEN, K., ZANG, W., NILSSON, H. and SAMUELSON, A. Creep damage in welds of steel X20 CrMoV 12 1. Varmeforsk report 874, Stockholm 2004. 20 p.

[3] BORGGREEN, K. and STORESUND, J. Creep behaviour of welds in X20 CrMoV 121 evaluated from replica inspection results. In Baltica VI-international conference on life management for power plants. vol. 2. HelsinkiStockholm: VTT, 2004. pp. 449-463.

[4] AUERKARI, P., HOLMSTROM, S., VEIVO, J. and SALONEN, J. Creep damage and expected creep life for welded 9-11\% Cr steels. International Journal of Pressure Vessels and Piping. 2007. vol. 84, pp. 69-74.

[5] MIDDLETON, C. J. and METCALFE, E. A review of laboratory Type IV cracking data in high chromium ferritic steels. In IMechE: Paper C386/027. London: Proceedings of IMechE, 1990.

[6] DOBRZANSKI, J. The classification method and the technical condition evaluation of the critical elements' material of power boilers in creep service made from the $12 \mathrm{Cr}-1 \mathrm{Mo}-\mathrm{V}$. Journal of Materials Processing Technology. 2005. vol. 164-165, pp. 785-794.

[7] STEJSKALOVÁ, Š., DORAZIL, O., FILIP, M., KOSŇOVSKÁ, J. and ROŽNOVSKÁ, G. Projekt Théta - Komplexní postupy materiálového inženýrství k zajištění bezpečného provozu inovovaných blokủ klasických elektráren, T60/2018, Ostrava: Materiálový a metalurgický výzkum, prosinec 2018 (in Czech).

[8] EN 15267, CD of standard. Small Punch Test Method for Metallic Materials. 2018.

[9] HEIDER, M. Evaluation of structure characteristics and properties of a X20CrMoV 11-1 steel after long-term service. Ostrava: Thesis, Technical University of Ostrava, Faculty of Materials Science and Technology. 2019, p. 54.

[10] KANDER, L. and STEJSKALOVÁ, Š. Study of mechanical properties and microstructure of weld joints tubes from austenitic steels after exposure in corrosion environment. T-46/2014 technical report, Ostrava, September 2014. 